\title{
Top management commitment for successful small and medium-enterprises(SMEs): A hoax or a reality?
}

\author{
Ndiritu Caroline \\ Kidombo Harriet, Prof. \\ Ndiritu Anne, Dr. \\ University of Nairobi
}

doi: 10.19044/esj.2016.v12n4p259 URL:http://dx.doi.org/10.19044/esj.2016.v12n4p259

\begin{abstract}
The role of small and medium enterprises in any country's economic development cannot be under estimated. It is important for all countries especially the developing ones to note that the key to having a sustained development is to improve the performance of small and medium enterprises (SMEs). This ensures economic growth is inclusive of all people. The success of these enterprises should be the concern of all governments that are interested in not only alleviating poverty as a major threat to sustainable development. The purpose of this study was to investigate the influence of top management commitment as a Total Quality Management (TQM) practice on performance of small and medium enterprises. The study concentrated on youth group projects in Kajiado north sub county, Kajiado County, Kenya. Youth projects were randomly selected from Kajiado north sub-county, in five wards. The study used mixed method approach in the data collection and analysis, to capture both the qualitative and quantitative data. The design is descriptive. The target population was 210 youth that were involved in youth group projects. Spearman's correlation was used to test the relationship between the variables. The analyses indicated that there is significant relationship between top management and performance.
\end{abstract}

Keywords: Small and medium enterprises, Total Quality Management, top management commitment and performance

\section{Introduction}

Different scholars have defined TQM practices differently based on the situations and type of organizations and industry. They have looked at it from different perspectives such as manufacturing organizations, service industry, government, healthcare, and banking and education sector. The scholars have also come up with different sets of TQM practices. One practice that seems to cut across them is top management commitment. This 
emphasizes on the importance of management for the success of any undertaking. According to Schultz (2003) the success or failure of any organization depends to a large measure on the quality of its leaders. For any organization to be successful, there must be an effective leader who is able to mobilize all the resources in the organization so as to achieve its goals. All enterprises would require leaders that are able to create within followers a capacity to develop higher levels of commitment to organizational goals. (Leithwood and Jantzi, 2000). Such leaders are expected to be exemplary role models for their followers, motivate them to be more committed to the vision of the organization, they encourage creativity and also act as advisors to their followers. Such kind of leaders displays transformational characteristics. Although TQM is about quality of product, this is only achievable if leadership is efficient and the processes within the organization are up to standards.

Management commitment has been found to affect the performance of all profitable organizations. The measure of performance can be shown by monetary aspects of the organization: what its market shares are, total sales, profits and other non-financial aspects of the employees which include: orientation towards quality, communication within organization, absenteeism, tardiness and their level of their training and skills employed (Kaplan \& Norton 1996). Emphasis of continual improvement of quality innovativeness and increased market shares results in reduction of costs and in turn improve financial performance of an organization (York \& miree 2004).

\section{Statement of the problem}

A lot of money has gone into the establishment of youth programmes. Youth projects that do not succeed is an indication that the Kenya youth empowerment project (KYEP) is not achieving its goal. This is because KYEP is a program initiated in 2010 with credit from the World Bank to support the government of Kenya to improve on the youth employability. There have been deliberate efforts to engage the youth in development. This is because youth development projects are a huge contributor towards the country’s GDP (Mburu \& Makori 2015). The divisional youth enterprise development fund committee (divisional YEDFC) was formed purposely to identify and assist functional youth groups in the region to access loans.

Unfortunately studies report that many youth projects do not succeed. For instance Mburu and Makori (2015) state that the issue that led to establishment of youth enterprise development fund YEDF in 2006 was due to the lack of engagement of youth in productive activities and high level of unemployment. They saw that about 55\% of the youth in Kenya are unemployed. The managerial issue comes out as a clear indication of the 
cause of inability to implement the youth projects. Attempts have been made to identify the causes of failure of youth projects. For instance,Amenya et al (2011) show that the causes of failure of youth projects are lack of funding, management skills, lack of stakeholder support. Mburu \& Makori (2006) support this by reporting that many fail because of managerial issues.

Bowen, Morara and Muriithi (2009) also have observed that over $50 \%$ of youth projects fail within the first three years. For instance the youth enterprise and development fund launched in 2006; has been on the decline as 57 million is reported to have been lost through misappropriation and mismanagement of funds, political interference and leadership wrangles. A 2009 World Bank funded project duped "kazi kwa vijana in Kenya collapsed in 2011 due to mismanagement and misappropriation of funds. According to youth initiative Kenya (2004) report, the main problem with the association and projects is that they are run by inexperienced youth who do not know how to handle youth affairs.

This study was guided by the following hypothesis:

\section{$H_{0}$ 1: There is no significant relationship between top management commitment and performance of SMEs.}

\section{Literature Review}

Total quality management is a management approach centred on quality, based on the participation of an organisation's people and aiming at long term success (ISO 8402:1994). This is achieved through customer satisfaction and benefits to all members of the organization and society.

There are several approaches of TQM practices. These practices have been defined based on the situations and type of organizations and industry. ISO for instance describes TQM as relating to quality of product, but this is only achievable if the processes within the organization are up to standards, leadership is efficient, the customer is the centre of focus, involvement of all the persons in the organization, systems approach to management, continual improvement of product, process and services, factual approach to decision making and finally mutual beneficial supplier relationship.

Other scholars such as Seraph et al (1998) studied seventy eight items in the manufacturing industry but finalized on eight items which were termed as the key TQM practices, role of divisional top management and quality policy, process management, product and service design, training, quality data and reporting, supplier quality management, role of quality department and employee relations. However on processing and production and implementation of TQM, Lu and Sohal (1993), created their nine practices of TQM; top management commitment, strategic quality management, process quality management, education and training, information analysis, benchmarking, resource and statistical process control. 
Flynn et al(1994) says that on quality management practices the following seven factors need to be followed as the TQM practices; top management support, product design, process management, quality information, supplier involvement, work force management and customer involvement. Powell (1995) identified twelve factors; committed leadership or executive commitment, employee empowerment, adoption and communication of TQM or adopting the philosophy, closer customer relationship, closer supplier relationship training, open organization, benchmarking, process improvement, zero defects mentality, measurements and flexible manufacturing.

Review of different TQM practices by different scholars seems to concur on the following major practices: top management commitment, process management, training of employees, quality of product design and quality information. This study will examine the influence of top management commitment on performance of SMEs.

Studies have shown that leadership improves on operation and performance. Senior managers are needed to lead the procedure of work, if this is possible then achievement of essential strategic principle during continual improvement will have been achieved. This method ensures every effort is quality orientation and customer oriented (Mohammadi 2014). Ndiritu (2015) summarizes the importance of commitment by saying that quality is "a boardroom affair". Its definition and initiative is by the commitment of the top management. Top management commitment helps in building trust with the employees. They are able to buy the idea of quality and employ the strategies in their daily activities within the organization. Top managers must always focus on developing skills and capacity of the employees by engaging them in training programs which are specially designed to increase the productivity and quality of goods and services. (Jones \& Grimshaw ,2012). Performance can be gauged by assessing management efforts to manage development and implementations of the project and programs in question.

Studies have shown that leaders who show commitment to their organizations perform better. By being committed their followers emulate the behavior which leads to the success of the organization. Knab (2009) asserts that such are transformational leaders who are able to develop trusting interactions through doing what they do or say that they are going to do succeed more.They set good examples by being committed through their daily acts that create progress. By setting the examples, the managers are able to demonstrate their commitment to the organization and its people. 


\section{Research methodology}

The study used mixed methods approach which involved collecting and analysing the quantitative and qualitative data. The independent variable was the TQM practice of Top management commitment and the dependent variable was performance of SMEs. The data was analysed using by Spearman's correlation to test whether there was any significant relationship between the variables. The target population was 168 youth in Kajiado north sub-county. These youth members were from groups that benefited from youth centre fundings, training and facility. Out of the 168 members a sample of 113 members were studied.Questionnaires and interviews were used as research instruments. For triangulation purposes, the interview schedule was used to confirm the information captured by the questionnaire.The youth groups were classified according to the industries they belonged to. Majority of the youth groups belonged to Art related industry accounting for $28.7 \%$, followed by service industry which accounted for $21.8 \%$. Other youth groups had the following proportions: "Jua kali"14.9\%, food industry 11.5\%, HIV/Aids related 5.7\% and I.T related accounted for $2.3 \%$.Others with less than one youth group accounted for $14.9 \%$.The quantitative data was analysed using the Pearson correlation while qualitative data was analysed using themes.

\section{Findings}

The indicators of the top management commitment were promotion of quality by top leaders, quality policy as an integral part of the group, level of open communication between leaders and members, frequency of communication from top leaders to the members, frequency of leaders communicating quality policy, objectives and processes, allocation of adequate resources with the aim of improving quality evaluation of top leaders on quality performance, formation of hierarchy of committee to ensure quality service improvement. Analyses were done for each indicator of top management commitment.

On promotion of quality by top leaders respondents were asked whether the top leaders were seen to promote quality within the youth group projects. A total of 79. respondents from the groups that were performing well agreed that their leaders promoted quality with a percentage of 94.057\%while five respondents that were from the groups not performing well agreed with a small percentage of 5.95\%. On quality Policy as an Integral Part of the Youth Group Projects, a large number of respondents (81) accounting for $94.19 \%$ from the groups performing well indicated that quality policy was an integral part of their youth group as compared to $5(5.82 \%)$ from the groups performing poorly. 
When questioned on the level of Open Communication between Leaders and Members, a total number of 82(95.35\%) respondents from the groups performing well, agreed that quality was promoted by the top leaders as compared to 5(4.65\%) whose groups were performing poorly. On frequency of Communication by Top Leaders to the Members, respondents from the groups performing well, indicated a higher agreement 82 (95.35\%) that there was frequent communication by the top leaders as compared to a small percentage (4.65\%) from their counterparts from the groups that were performing poorly. These findings were similar to the one on the level of open communication between the leaders and the members probable because they were on the same subject. The other indicator was on the frequency of Leaders Communicating Quality Policy, Objectives and Processes. A total of $83(94.13 \%)$ respondents from the groups performing well agreed that quality was promoted by the top leaders as compared to 5(5.68\%) gotten from the respondents originating from the poorly performing groups.

An analysis was also done on of how adequate resources were allocated with the aim of promoting quality in the youth group projects. A large percentage (95.4\%) of respondents from the groups performing well agreed that presence of adequate resource was promoted by the top leaders as compared to a percentage $4(4.598 \%)$ respondents from the poorly performing groups.

The last two indicators indicated a similar trend. According to the analyses, a total of $83(95.4 \%)$ respondents agreed that there was an evaluation of top leaders based on quality management as compared to a small percentage $(4.597 \%)$ from their counterparts from the poorly performing groups. This trend was also observed on the Last indicator which was on formation of hierarchy of committee to ensure quality service improvement on Performance of the youth group projects. Analysis showed that there was formation of hierarchy of committee to ensure quality service improvement in groups performing well accounted for $(94.19 \%)$ than in poorly performing groups which indicated $5.814 \%$.

\section{Hypothesis testing}

The Statistical Package for Social Sciences (SPSS) software was used to determine the possible relationships between top management commitment and performance of SMEs. The mean of top management commitment was 162.2 and the mean for performance of SMEs was 151.75. A Spearman's rank order correlation was run to determine the relationship between top management commitment and performance of youth group projects. From the analysis,there was a moderate positive correlation between top management commitment and performance of SMEs, which was statistically significant $r_{s}=0.400, p=0.60$. Therefore the null hypothesis 
was rejected and the alternative hypothesis accepted. There is indeed a significant relationship between top management commitment and performance of SMEs.

\section{Discussions and findings}

The study established a positive relationship between top management and performance of SMEs. This is in line with Moorman et al (1993) studies who found a strong positive relationship between effective commitment and job performance. However, the study contradicts Meyer and Allen (1991) study, Meyer et al (1989) and Konovsky and Cropanzano (1991) studies which argued that the commitment to the organization is not in any way related to the job performance in the organization. A strong commitment to the organization by the employees results to the individuals being punctual, builds flexibility and ability of the individuals to take up extra roles that are not in their job specification. A strong commitment leads to acquisition of self motivation, makes one a team player and builds the relationship among the employees.

Studies have shown that leadership improves on operation and performance. Senior managers are needed to lead the procedure of work by showing commitment to their work. When leaders show commitment, members are likely to work harder for accomplishment of organizational objectives. Kouzes and Posner (2002) calls this modeling the way of transformational leadership. This leadership cultivates a culture in which people are committed and loyal as well as take pride in the organization and its work. This commitment ensures that every effort is geared towards quality orientation and customer orientation. In addition the study recommends open communication between leaders and members. Top leaders should also form a hierarchy of committees to ensure continued service improvement. Performance can be gauged by assessing management efforts to manage development and implementations of the project and programs in question.

\section{References:}

Bowen, M., Morara, M Mureithi, S (2009) Management of business challenges among small and micro-enterprises in Nairobi-Kenya. Journal of Business management 2(1) 16-31

Flyyn, B.B., Schroder, R.G., Sakakibara, S. (1994). A Framework for Quality Management Research and an Associated Measurement Instrument. Journal of Operations Management, 11, 339-366.

Davood Gharakhani , Hossein Rahmati, Mohammad Reza Farrokhi, Arshad Farahmandian (2013) Total quality management and organizational 
performance.American Journal of Industrial Engineering, 20131 (3), pp 4650. DOI: 10.12691/ajie-1-3-2

Jones, B., \& Grimshaw, D. (2012). Training and skills to improve innovation in firms (pp. 1-38). Manchester.

Kaplan, R.S and D.P Norton (1996). Using the balanced scorecard as a strategic management system, Harvard Business Review (January-February) 75-85)

Knab. D. (2009). A Comparison of the Leadership Practices of Principals of Making Middle Grades work schools as Measured by the Leadership Practices Inventory Volume 7 issue 3 summer 2009. Academic online journal. Retrieved $25^{\text {th }}$ January, 2016

Koonovsky, M.A., \& Cropanzaro (1991) Perceived fairness of employee drug testing as a predictor of employee attitudes and job performance. Journal of applied psychology 76(5):698-707

Kouzes,J., \& Posner, B. (2002). The leadership challenge ( $3^{\text {rd }}$ ed.). San Francisco, CA: Jossey-Bass

Leithwood, K., \& Jantzi, D. (2000). “The effects transformational leadership on organizational conditions and student engagement”. Journal of Educational Administration, 38(2), 112-129

Lu, E., Sohal, A. (1993). Success factors, weaknesses and myths concerning TQM Implementation in Australia. Total Quality Management, 4(3), 245256.

Saraph, J.V., Benson, P.G. and Schroeder, R.G. (1989), “An instrument for measuring the critical factors of quality management”, Decision Sciences, Vol. 20 No. 4, pp. 810-29.

Shultz, D. e (2003) So you want to be a branding guru? Marketing management 12(2), 8-9

Powell, T. (1995). Total quality management as competitive advantage: a review and empirical study. Strategic management journal, 16(1). 5-37

Mburu, M \&Makori, M (2015) Management challenges facing the implementation of youth development projects in Kenya. A case study of youth enterprise funded projects in Nairobi

County; Strategic journal of business change and management, 2(34) 636661

Meyer, J.P Paunonew, S,VGellatly, I.R Goffin, R.D \& Jackson, D.N (1989) Organizational commitment and job performance: It's the nature that commitment that countss. Journal of applied Psychology, 74: 152-156

Moorman, R.H, Niehaff, B.P \& Organ, D.W (1993) Treating employees fairly organizational citizenship behavior: sorting the effects of job satisfaction, organizational commitment and procedural justice. Employee responsibility and rights journal, 6: 209-225 
Ndiritu, C.M.N (2015) Influence of Total Quality Management practices on performance of small and medium enterprises: A case of youth groups projects in Kajiado North sub county, Kajiado county, Kenya. Unpublished Masters in Project Planning and Management research project, University of Nairobi

York, K.M.,\& Miree. C.E., (2004) Causation or covariation” An empirical re-examination of the link between TQM and financial performance. Journal of operations management 22(3) 291-3311. 